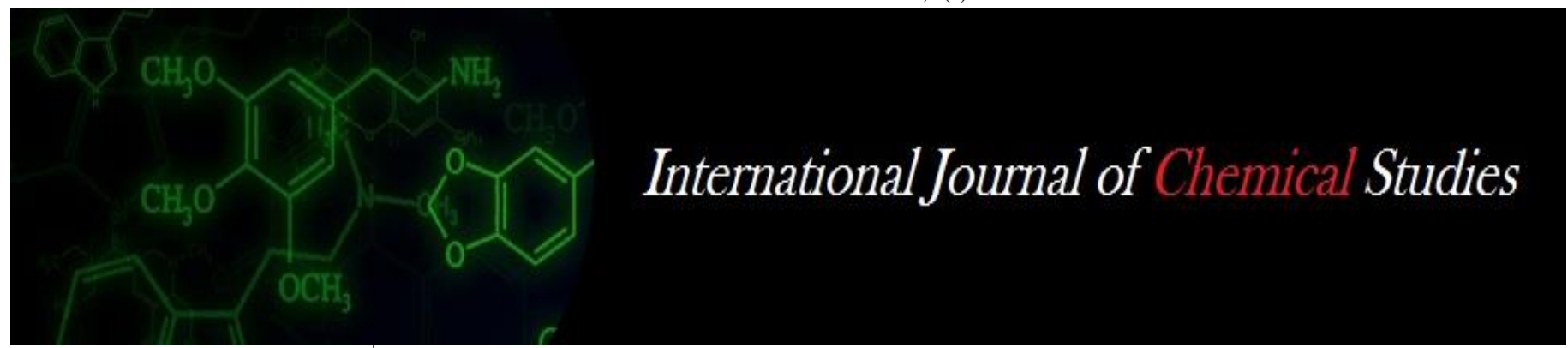

P-ISSN: 2349-8528

E-ISSN: 2321-4902

www.chemijournal.com

IJCS 2020; 8(2): 532-537

(C) 2020 IJCS

Received: 14-01-2020

Accepted: 20-02-2020

\section{Sukhjit Kaur}

Punjab Agricultural University,

Regional Research Station,

Gurdaspur, Punjab, India
Corresponding Author:

Sukhjit Kaur

Punjab Agricultural University,

Regional Research Station,

Gurdaspur, Punjab, India

\title{
To study the effect of different concentrations of plant growth regulators on rooting of litchi (Litchi chinensis Sonn.) air layers
}

\section{Sukhjit Kaur}

DOI: $\underline{\text { https://doi.org/10.22271/chemi.2020.v8.i2h.8822 }}$

\begin{abstract}
The present experiment entitled "To study the effect of different concentrations of plant growth regulators on rooting of litchi (Litchi chinensis Sonn.)) Air layers" was conducted at Punjab Agricultural University, Regional Research Station, and Gurdaspur during the year 2015-16 and 2016-17. The experiment was laid out in Randomized Block Design with thirteen treatments of different concentrations of plant growth regulators each of IBA and NAA i.e.1000ppm, 2000 ppm, 3000 ppm, 4000ppm, $5000 \mathrm{ppm}$ and $6000 \mathrm{ppm}$ and replicated thrice with a unit of one plant in each replication of a treatment. The result showed that among different application of IBA (Indole-3-butyric acid), the $5000 \mathrm{ppm}$ IBA treated layers took lesser days to root initiation (16days) and also gave better results with respect to all the parameters studied including per cent rooting (90.45\%), number of roots (35.52), root length $(12.5 \mathrm{~cm})$, percent survival $(95.25)$, days to come leaf after detachment (12days), root thickness $(1.62 \mathrm{~mm})$, fresh weight of root $(3.35 \mathrm{gm})$, dry weight of $\operatorname{root}(2.15 \mathrm{gm})$,fresh weight of shoot $(52.25 \mathrm{gm})$, dry weight of shoot $(32.25 \mathrm{gm})$ and root: shoot ratio on dry weight basis $(0.067)$ as compared to other treatments along with control. Similarly, among different treatments of NAA(1-Naphthaleneacetic acid), the 5000ppm NAA treated layers took lesser days to root initiation (20 days) and also gave better results with respect to all the parameters studied including per cent rooting (80.5), number of roots (30.25), root length $(10 \mathrm{~cm})$, percent survival $(84.2)$, days to come leaf after detachment (14), root thickness $(1.42 \mathrm{~mm})$, fresh weight of root $(2.75 \mathrm{gm})$, dry weight of root $(1.50 \mathrm{gm})$, fresh weight of shoot $(47.65 \mathrm{gm})$, dry weight of shoot (27.42gm) and root: shoot ratio on dry weight basis (0.04) as compared to other treatments along with control.
\end{abstract}

Keywords: IBA, NAA, rooting, air-layers, litchi (litchi chinensis Sonn.)

\section{Introduction}

The litchi (Litchi chinensis Sonn.) recognized as "Queen of the fruits" is one of the most environmentally sensitive sub-tropical evergreen fruit tree, belongs to family Sapindaceae (Haq et al., 2013) ${ }^{[1]}$. It is indigenous to south eastern China from where it is considered to have reached eastern India through Myanmar by the end of $17^{\text {th }}$ century or shortly thereafter (Hayes, 1957) ${ }^{[2]}$. In India, 686 thousand metric tonnes of litchi is produced annually from 92 thousand hectares area (Annonymous, 2018) ${ }^{[3]}$. It is highly specific to climatic requirements, as it required cool dry winters and warm wet summers and due to this reason its cultivation is restricted to few states in our country. Litchi is grown mainly in the states of Bihar, West Bengal and Uttar Pradesh. It is also grown in limited scale in Tripura, Orissa, Punjab, Himachal Pradesh, Assam and Nilgiri hills in the south. In Punjab, its cultivation recommended to sub-mountainous tracts of Gurdaspur, Hoshiarpur, Roopnagar, SAS Nagar Mohali and Patiala districts. In Punjab, litchi is growing in an area of 2885 hectares with the production of 46940 metric tonnes (Annonymous, 2019) ${ }^{[4]}$. Litchi is an arillate and nut type fruit botanically which is known for its excellent quality, juicy, slightly sour and sweet taste, characteristic pleasant flavour, attractive colour and nutritional value. The fruit is rich in sugars, minerals and vitamins (Marisa, 2006) ${ }^{[5]}$ and can be processed into juice, wine, pickles, jam, jelly, ice cream and yoghurt (Huang et al., 2005) ${ }^{[6]}$. It comes to the market in the months of May-June when the market is full of other fresh fruits. But, inspite of the availability of different types of fruit in the market, the demand for fresh litchi is always very high due to its unique taste, flavour and colour (Hossain et al., 2014) ${ }^{[7]}$. 
Its fruit has gained popularity as an exotic fruit and that is why demand of planting material of litchi is increasing tremendously. Limited availability of quality planting material is the main cause of low expansion of area under litchi cultivation. The shortage of genuine planting material coupled with the long juvenile period of litchi is one of the major constraints for mass multiplication. Propagation of litchi by seed is not usually recommended, since litchi seedlings are genetically diverse and most are characterised by a long juvenile period.

Several vegetative propagation techniques as air layering, root cuttings and stooling, have been tried with varying success rate to increase productivity and gains by clonal propagation and selection (Berthon et al., 1990; Casimiro et al., 2001) ${ }^{[8,9]}$. Though these techniques are still not commercially viable due to varying rate of success, absence of tap root system and cumbersome process.

The most commonly practiced and commercial method of vegetative propagation in litchi is air-layering. Air-layering is done when leaves of the previous growth flush have proper maturity. Air layering can be done at any time of years as long as there is sufficient moisture, however more ideal results are reported in rainy season. The principle of layering is to encourage development of newly emerge roots on a stem while the stem is still attached to the parent plant. Roots emerge on the aerial part of a plant after the girdling of stem at an angle and enclosed in a moist rooting medium at the point of injury in air layering. Air layers are usually made on wood of the previous season's growth.

The major tail back in the air layering is the high mortality of layered shoots after separating from parent plants and establishment in the nursery on their own root system (Sharfuddin,1983; Sharma et al., 1990; Syamal and Singh, 1993) ${ }^{[10,11,12]}$. Thus, it results in a very limited availability of plants of elite genotype. Plant growth regulators like IBA, NAA are very useful in accelerating the rooting in air layered litchi (Rajwana et al., 2008) ${ }^{[13]}$. Cell enlargement, bud formation and root initiation are positively influenced by auxins. Growth and development of plants are affected by plant growth regulators due to metabolic and physiological responses. Various stem treatments lead to formation of adventitious roots during air layering, which causes wounding of a small part of the stem, that resulting in to the interruption of the downward movement of organic material such as carbohydrate, auxin and growth factor from the leaves and shoot tips. This material accumulates close to the treated area and rooting follows. Thus earlier layering was done using clay soil having provision of watering. However, the air-layer practiced now uses growth hormone and sphagnum moss (a nutrient mixed media). Sphagnum moss is a natural organic soil conditioner, which helps to regulate temperature, moisture and air around plant roots, creating ideal growing conditions. Sphagnum moss aerates plant roots by loosening heavy clay soil. It saves water by absorbing and holding moisture and reduces leaching or runoff of nutrients presents in or added to the soil (Hartmann and Kester, 1975) ${ }^{[14]}$

To find out optimum dose of NAA and IBA in air layering of litchi, this study was carried out for minimizing the mortality and promoting better growth of litchi layers in nursery resulting in maximum number of true to type plants. The main objective of this study was to assess the suitable concentration of indole-3-bytyric acid (IBA) and 1-Naphthalene acetic acid (NAA) for the production of true to type plants of litchi in short period of time employing air layering method of propagation.

\section{Materials and Methods}

The present experiment was conducted at litchi orchard of Punjab Agricultural University, Regional Research Station, and Gurdaspur during the year 2015-16 and 2016-17. Uniform, vigorous, healthy and disease free plants of cultivar Dehradun were selected for layering operation during month of mid- July and August after the onset of rains and maintained with uniform cultural practices as recommended by Punjab Agricultural University, Ludhiana.

For air layering operation, one year old terminal branch, 45$60 \mathrm{~cm}$ long and $2-2.5 \mathrm{~cm}$ thick was selected. A $4 \mathrm{~cm}$ wide circular ring of bark on twig was removed with a sharp knife. The exposed cambium was rubbed off and plant growth regulators of different concentrations each of IBA and NAA i.e. $1000 \mathrm{ppm}, 2000 \mathrm{ppm}, 3000 \mathrm{ppm}, 4000 \mathrm{ppm}, 5000 \mathrm{ppm}$ and $6000 \mathrm{ppm}$ were smeared in lanolin paste at the upper end of the girdled part of the branch and compared with the control where no chemical was used. Experiment was laid out in Randomized Block Design (RBD) with replications.

Subsequently girdled/exposed area was covered with moistened sphagnum moss grass and wrapped with a piece of 200 gauge polyethylene film of $10 \times 10 \mathrm{~cm}$ size to prevent desiccation and both the ends of polythene was firmly tied with the help of a 'sutli' string. The layers were detached from the mother plants when the roots were visible. The air layered branch or the gootee were severed from the mother tree only when a good number of roots were developed. After severing from the mother tree, removed the polythene sheet and immediately planted the gootee in a nursery bed. Irrigation was applied to the gootee after plantation in the nursery.

Data were recorded on parameters including days taken to root appearance, percentage rooting, number of roots, root length, percentage survival, days to come leaf after detachment, root thickness, fresh weight of root, dry weight of root, fresh weight of shoot, dry weight of shoot, and root: shoot ratio on dry weight basis. Data was analysed statistically by Randomized Block Design as described by Singh et al. (1998) ${ }^{[15]}$ for each year and ultimately the pooled estimates for both the years were worked out.

\section{Results and Discussion}

\section{Number of days taken for root initiation}

Plant growth regulators IBA and NAA when applied at different concentrations had significant influence on the appearance of root causing earliness in rooting of air-layers of litchi (Table 1).

From Table 1, it was observed that with IBA treatment, the minimum number of days taken for root initiation (16 days) was recorded with IBA 5000 ppm, while control took highest number of days for root initiation (28 days). Similarly, minimum number of days taken for root initiation (20 days) with NAA 5000ppm.IBA treatments might have resulted in early rise in root co-factors and fall in root inhibitors level leading to early rooting. In addition, exogenous application of auxins could have converted starch into simple sugars, which is required to a greater extent for the production of new cells and for the increased respiratory activity in the regenerating tissues at the time of initiation of new root primordial (Nanda, 1975) ${ }^{[16]}$.

\section{Percent rooting}

Significantly higher per cent rooting $(90.45 \%)$ was recorded with IBA $5000 \mathrm{ppm}$ (Table 1). These results are in agreement with the findings of Ray et al. (2001) ${ }^{[17]}$. This might be due to 
the fact that optimum concentration of IBA may have caused mobilization and utilization of carbohydrates and nitrogen fraction with the presence of co-factors at wound site which may have helped in better root initiation. Hence, IBA at higher concentration resulted in better rooting of the litchi air layers.

It was also noted that the among NAA treatment, maximum rooting percentage $(80 \%)$ was observed in the shoots treated with NAA $5000 \mathrm{ppm}$. Minimum rooting percentage $(60.25 \%)$ was observed in control (Table 1). This study is confirmatory to the findings of Tomar et al. (1999) ${ }^{[18]}$; Sharma (1981) ${ }^{[19]}$ who found NAA is most effective for rooting of air layering. Further the superiority of IBA in producing higher percentage of rooting compared to NAA might be due to their respective differences in initializing hydrolysis of nutritional reserves. These results further get support from the findings of Sharma (1990) ${ }^{[20]}$ in litchi and Lal et al. (2007) ${ }^{[21]}$ in guava.

Exogenous application of IBA markedly improved the regeneration of roots in comparison to NAA. The greater effectiveness of IBA over NAA may be due to its non-toxic nature in a wide range of concentration and was effective in promoting rooting of large number of plant species. Significant increase in rooting percentage due to combination of IBA and sphagnum moss has also been reported by Das et al. (2014) ${ }^{[22]}$ as well as Eed and Burgoyne (2014) ${ }^{[23]}$.

\section{Number of roots}

The highest number of roots (35.52) was observed in IBA $5000 \mathrm{ppm}$, while lowest was in control. Accelerated rooting in the layering with the increased IBA concentration might be due to increased cell wall elasticity which further may have accelerated cell division and in turn increased number of roots up to certain level. This might be due to increase in carbohydrate and metabolic activities. Bora et al. (2006) [24] also reported increase in the number of second order roots with increase in concentration of IBA, and the increase in treated layers was possibly due to the fact that IBA influenced acceleration of the rate of initiation of root meristems and consequently production of greater number of roots (Sharfuddin, 1983) ${ }^{[10]}$. These results are corroborated by the findings of the work on litchi (Singh et al., 2009; Ray et al.,

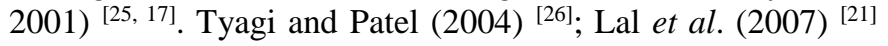
also reported similar findings in guava.

The increase in number of roots may be due to accumulation of carbohydrates, enhanced protein synthesis and greater accumulation of rooting co-factors. Rooting co-factors react with auxin and a large number of roots were produced. Positive response of the rooting media was also observed by Das et al. (2010) [22]; Das and Prasad (2014) [27]; Brahamchari

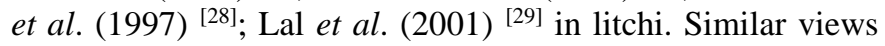
related to secondary root were also expressed by (Chatterjee, 1982) ${ }^{[30]}$ in mango and (Pathak et al., 1975) $\left.{ }^{[31}\right]$ in plum.

Among different NAA treatments, the highest number of roots (30.25) was noted in NAA 5000ppm. This study is confirmatory to the findings of (Tomar, 1979) ${ }^{[32]}$ and (Sharma, 1981) ${ }^{[19]}$ who found NAA is most effective for rooting of air layering.

\section{Root length}

Among various IBA treatments, maximum total length $(12.5 \mathrm{~cm})$ of first order roots was recorded with application of 5000 ppm IBA, whereas minimum in control $(5.0 \mathrm{~cm})$.

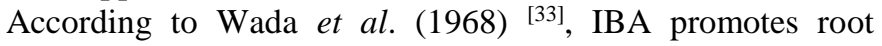
length by influencing the synthesis of enzymes which are concerned with the cell enlargement. The enzymes involved in cell enlargement process are triggered by the auxin at higher concentration. The increase in root length with different concentrations of growth regulators, IBA (5000 $\mathrm{ppm}$ ) may be attributed to its primary physiological effect which is known to promote the elongation of cells in the apical region, a reason which has been cited by Singh et al. (2009) ${ }^{[34]}$ in air layers of litchi. The similar results were reported by Ray et al. (2001) ${ }^{[17]}$; Bora et al. (2006) ${ }^{[24]}$; Rahman et al. (2002) ${ }^{[35]}$ in litchi.

Singh et al. (2007) ${ }^{[36]}$ in guava and Bhosale et al. (2010) [37] in pomegranate who also observed higher total length of first order root when treated with IBA at higher concentration.

The increase in length of roots may be due to increase in level of auxin concentration. Auxin elongated the length of primary and secondary roots. IBA in higher concentration causes antagonistic effect on secondary roots. The same viewed were expressed by Chawla et al. (2012) ${ }^{[38]}$ as well as Das and Prasad (2014) ${ }^{[27]}$ in litchi.

Similarly among different NAA treatments, the maximum root length $(10 \mathrm{~cm})$ was recorded with NAA 5000ppm.

\section{Survival percentage}

The air-layer raised by the application of IBA $5000 \mathrm{ppm}$ gave significantly higher survival percentage (95.25). Similarly, maximum survival percentage (84.2) was observed in the shoots treated with NAA at the rate of 5000ppm. These results display resemblance with the findings of Tomar et al. (1999) ${ }^{[18]}$ who observed maximum success percentage in air layering with application of NAA.

The increase in survival percentage may be due to profuse and thinner root produced by the application of different treatments. Thinner root system increased water absorption capacity, which reduced mortality rate in the nursery. Finding of the trial was in close conformity with findings of Patel et al. (2012) ${ }^{[39]}$ in pomegranate, Sen et al. (1961) ${ }^{[40]}$ in mango as well as Das and Prasad (2014) ${ }^{[27]}$ in litchi.

\section{Root thickness}

With IBA 5000 ppm, maximum mean root thickness $(1.62 \mathrm{~mm})$ was obtained, while minimum $(0.78 \mathrm{~mm})$ was recorded in control (Table 2). Kumar (2009) ${ }^{[41]}$ also noticed conspicuous effect which was attributed due to higher concentration of IBA in litchi layers. Slow translocation and higher stability of IBA at higher concentration might be attributed to increase in the mean root thickness. The better effect of 5000 ppm IBA in the present study is in general agreement with the findings of Sinha and Ray (2002) ${ }^{[42]}$ in litchi and Hatibarua et al. (1997) ${ }^{[43]}$ in jackfruit.

Among different NAA treatments, maximum root thickness $(1.42 \mathrm{~mm})$ was observed with NAA 5000ppm treatment, while minimum $(0.78 \mathrm{~mm})$ was recorded in control.

\section{Fresh weight and dry weight of root}

Both fresh and dry weight of roots were markedly influenced by plant growth regulators (Table 2). The highest fresh $(3.35 \mathrm{gm})$ and dry weight $(2.15 \mathrm{gm})$ of roots were recorded with IBA $5000 \mathrm{ppm}$ which performed better as compared to all other treatments and lowest values were obtained in control. These results are corroborated by the findings of Ray et al. (2001) ${ }^{[17]}$; Singh and Jawandha (1981) ${ }^{[44]}$ in litchi. The highest roots weight registered in the present study may be attributed to the fact that exogenous application of auxin generally stimulate the movement of natural auxin and others materials in downward direction from leaves and shoot tips, which accumulate at the incision made on the shoot resulting 
in the formation of roots with higher root fresh and dry weight. This might be due to more number of primary and secondary roots and also with, more length in case of layers treated with IBA $5000 \mathrm{ppm}$. Similar findings have been observed by Tyagi and Patel (2004) ${ }^{\text {[26] }}$ Rymbai and Reddy (2010) ${ }^{[45]}$ in guava, Kumar et al. (2007) ${ }^{[46]}$ in jack fruit and Bhosale et al. (2010) ${ }^{[37]}$ in pomegranate.

\section{Fresh and dry weight of shoot}

The fresh weight and dry weight of shoot under different treatments were found to be significant in different growth regulators treatment (Table 2). IBA at $5000 \mathrm{ppm}$ resulted in maximum fresh weight $(52.25 \mathrm{gm})$ and dry weight $(32.25 \mathrm{gm})$ of shoot while minimum was found in control. Similar findings were also observed by Shukla and Bist(1994) ${ }^{[47]}$ in pear who concluded that IBA at higher concentration showed maximum dry weight of shoot of cutting. Similarly maximum fresh weight $(47.65 \mathrm{gm})$ and dry weight $(27.42 \mathrm{gm})$ of shoot were found in NAA 5000ppm while minimum was found in control.

\section{Root shoot ratio on dry weight basis}

The higher root: shoot ratio was registered in IBA 5000 ppm (0.067) and NAA 5000ppm (0.04), while minimum was observed under control. Higher concentration of IBA might have caused increased mobilization and utilization of carbohydrates and nitrogen fraction to the growing litchi layers which helped them to put more vegetative mass by virtue of which more photosynthates were translocated downward to the roots resulting in an increase in the said parameter. Plants with a higher proportion of roots can compete more effectively for soil nutrients, while those with a higher proportion of shoots can intercept and absorb more light energy. Large proportions of shoot production are characteristic of vegetation in early phases, while high proportions of root production are characteristic of late phases. Roots allow a plant to absorb water and nutrients from the surrounding soil, and a healthy root system is key to a healthy plant. Better root: shoot ratio parameter helps to assess the overall health of the plants.

\section{Days to come out leaf emergence}

The data pertaining to the days to come leaves after detachment as a result of different treatment has been resulted significantly. From Table1, it was indicated that early leaf initiation (12 days) was recorded in IBA 5000ppm and NAA 5000ppm (14days). All the treatments were significantly superior over control in respect of early leaf initiation. Early leaf development may be due to a uniform spread and number of primary and secondary roots system who absorbed sufficient nutrient and water resulting in quick establishment of layers, better morphological growth and leaves. This result was supported by Ray et al. (2001) ${ }^{[17]}$.

\section{Conclusion}

From the present study it is concluded that IBA at $5000 \mathrm{ppm}$ and NAA 5000 ppm proved superior in terms of earlier root initiation, rooting percentage, number of roots, root length, survival (\%), days to come leaf after detachment, root thickness (mm), fresh weight of root (gm), dry weight of root (gm), fresh weight of shoot (gm), dry weight of shoot (gm) and root: shoot ratio on dry weight basis.

Table 1: Effect of plant growth regulators on root initiation and different rooting characteristics of air layers of litchi

\begin{tabular}{|c|c|c|c|c|c|c|}
\hline Treatments & Days taken to root appearance & Rooting (\%) & Number of roots & Root length(cm) & Survival (\%) & Root thickness (mm) \\
\hline IBA 1000ppm & 25.25 & 71.15 & 22.11 & 6.52 & 75.45 & 1.08 \\
\hline IBA 2000ppm & 24.53 & 74.14 & 24.15 & 7.12 & 78.24 & 1.22 \\
\hline IBA 3000ppm & 22.14 & 77.15 & 27.32 & 8.45 & 80.12 & 1.3 \\
\hline IBA 4000ppm & 20.55 & 80.26 & 29.52 & 9.22 & 83.4 & 1.32 \\
\hline IBA 5000ppm & 16 & 90.45 & 35.52 & 12.5 & 95.25 & 1.62 \\
\hline IBA 6000ppm & 22.35 & 78.12 & 25.13 & 8.65 & 81.24 & \\
\hline NAA 1000ppm & 25.54 & 65.24 & 19.36 & 5.5 & 70.52 & 0.96 \\
\hline NAA 2000ppm & 25.1 & 68.3 & 22.18 & 6.25 & 72.45 & 0.85 \\
\hline NAA 3000ppm & 24.25 & 72.16 & 25.13 & 7.52 & 76.12 & 0.92 \\
\hline NAA 4000ppm & 23.15 & 75.32 & 27.15 & 8.5 & 80.15 & 1.15 \\
\hline NAA 5000ppm & 20 & 80.5 & 30.25 & 10 & 84.20 & 1.2 \\
\hline NAA 6000ppm & 21.13 & 72.32 & 21.32 & 6.75 & 77.3 & 1.42 \\
\hline Control & 28 & 60.25 & 14.52 & 5 & 68.26 & 0.92 \\
\hline CD (5\%) & 2.63 & 3.11 & 3.13 & 2.07 & 3.22 & 0.78 \\
\hline
\end{tabular}

Table 2: Effect of plant growth regulators on root and shoot biomass characteristics of air layers of litchi

\begin{tabular}{|c|c|c|c|c|c|c|}
\hline Treatments & $\begin{array}{l}\text { Fresh weight of } \\
\operatorname{root}(\mathrm{gm})\end{array}$ & $\begin{array}{l}\text { Dry weight of } \\
\operatorname{root}(\mathrm{gm})\end{array}$ & $\begin{array}{l}\text { Fresh weight of } \\
\operatorname{shoot}(\mathrm{gm})\end{array}$ & $\begin{array}{c}\text { Dry weight of shoot } \\
(\mathrm{gm})\end{array}$ & $\begin{array}{c}\text { Root: shoot ratio on } \\
\text { dry weight basis }\end{array}$ & $\begin{array}{c}\text { Days to come leaf after } \\
\text { detachment }\end{array}$ \\
\hline IBA 1000ppm & 2.23 & 0.8 & 44.25 & 22.13 & 0.036 & 19.25 \\
\hline IBA 2000ppm & 2.38 & 0.95 & 45.15 & 24.6 & 0.039 & 18.25 \\
\hline IBA 3000ppm & 2.5 & 1.12 & 46.2 & 25.55 & 0.044 & 17.16 \\
\hline IBA 4000ppm & 2.15 & 1.25 & 47.14 & 26.75 & 0.047 & 16 \\
\hline IBA 5000ppm & 3.35 & 2.15 & 52.25 & 32.25 & 0.067 & 12 \\
\hline IBA 6000ppm & 2.6 & 1.15 & 46.72 & 25.42 & 0.045 & 15.1 \\
\hline NAA $1000 p p m$ & 1.25 & 0.52 & 44.1 & 23.25 & 0.022 & 20 \\
\hline NAA 2000ppm & 1.52 & 0.6 & 45 & 24.12 & 0.025 & 19.52 \\
\hline NAA 3000ppm & 1.78 & 0.75 & 45.75 & 25.65 & 0.029 & 18.15 \\
\hline NAA 4000ppm & 1.95 & 0.88 & 46.13 & 26.52 & 0.033 & 17.5 \\
\hline NAA 5000ppm & 2.75 & 1.50 & 47.65 & 27.42 & 0.04 & 14 \\
\hline NAA 6000ppm & 1.75 & 0.72 & 45.1 & 25.14 & 0.029 & 17 \\
\hline Control & 1.85 & 0.6 & 42 & 20.35 & 0.029 & 22.45 \\
\hline $\mathrm{CD}(5 \%)$ & 0.91 & 0.41 & 3.47 & 3.17 & 0.002 & 2.54 \\
\hline
\end{tabular}




\section{References}

1. Haq I, Rab A, Sajid M. Foliar application of calcium chloride and borax enhance the fruit quality of litchi cultivars. Journal of Animal and Plant Sciences. 2013; 23(5):1385-1390.

2. Hayes WB. Fruit growing in India. Kitabistan, Allahabad, 1957.

3. Annonymous. Area and production of different fruits in India. National Horticulture Board, India, www.nhb.gov.in, 2018.

4. Annonymous, Package of practices for cultivation of fruits. Punjab Agricultural University, Ludhiana, 2019.

5. Marisa MW. Ascorbic acid and mineral composition of longan, lychee and rambutan cultivars grown in Hawaii. Journal of Food Composition and analysis. 2006; 19:655663.

6. Huang XM, Wang HC, Li JG, Yin JH, Yuan WQ, Lu JM. An overview of calcium's role in lychee fruit cracking. Acta Horticulturae. 2005; 665:231-240.

7. Hossain MM, Hossain MS, Islam MM. Fruit setting, cracking and quality of litchi as influenced by foliar spray of different nutrient solutions during fruit growth and development. Journal of Agricultural Technology. 2014; 10(3):717-731.

8. Berthon JY, Tahar B, Boyer GT. Rooting phases of shoots of Sequoiadendrongiganteum in vitro and their requirements. Plant Physiology and Biology. 1990; 28:631-638.

9. Casimiro I, Marchant A, Bhalerao RP, Beeckman T, Dhooge S, Swarup R et al. Auxin transport promotes arabidopsis lateral root initiation. Plant Cell. 2001; 13:843-852.

10. Sharfuddin AFM. Effect of pruning on the survival of detached rooted air layers in litchi. Bangladesh Horticulture. 1983; 11:39-40.

11. Sharma SB, Ray PK, Singh BK. Notes on rooting and survival of litchi layers. Indian Journal of Horticulture. 1990; 47:174-176.

12. Syamal MM, Singh SK. Effect of etiolation and plant growth substances on rooting of air layers in litchi. Indian Journal of Horticulture. 1993; 50:242-244.

13. Rajwana IA, Malik AU, Khan AS, Anwar R. Lychee industry in Pakistan: Potential and prospects. Acta Horticulturae. 2008; 863:67-72.

14. Hartmann HT, Kester DE. Plant Propagation: Principles and Practices. 3rd ed. Englewood cliffs, N. J., USA: Prentice Hall, Inc, 1975, 455-476.

15. Singh S, Bansal ML, Singh TP, Kumar P. Statistical Methods for Research Workers. Kalyani Publishers, New Delhi, 1998.

16. Nanda KK. Physiology of adventitious root formation. Indian Journal of Plant Physiology, 1975; 18:80-90.

17. Ray RN, Dwivedi AK, Rao PS, Jain BP. Effect of indole butyric acid and coloned wrapping material on propagation of litchi cv. Purbi. Haryana Journal of Horticultural Sciences. 2001; 30(3-4):170-172.

18. Tomar KS, Gurjar BS, Tomar RSS. Response of different concentrations of IBA and NAA on rootage and growth of air-layers of guava (Psdium guajava L.)cv. Gwalior-27. Advances in Plant Science. 1999; 12(2):535-538.

19. Sharma SK. Cooperative studies on rootage and growth of karonda (Carissa carandas L.) airlayers. Thesis submitted to Jawaharlal Nehru Krishi Vishwavidyalaya, Jabalpur, 1981.
20. Sharma SB, Ray PK, Singh BK. A note on rooting and survival of litchi layers. Indian Journal of Horticulture. 1990; 47(2):174-176.

21. Lal S, Tiwari JP, Awasthi P, Singh G. Effect of IBA and NAA on rooting potential of stooled shoots of guava Psidium guajava L. cv. Sardar. Acta Horticultura. 2007; 735:193-196.

22. Das AK, Singh KP, Kumar R, Patel B, Ranjan A. Response of bio-regulators on air layering in litchi cv. Purbi. The Asian Journal of Horticulture. 2014; 9(2):505506.

23. Eed A, Burgoyne A. Effect of different rooting media and plant growth regulators on rooting of Jojoba (Simmondsia chinensis (Link) Schneider) semi-hard wood cuttings under plastic tunnel conditions. International Conference on Agricultural, Ecological and Medical Sciences, February, Bali (Indonesia), 2014, 6-7.

24. Bora N, Lal RL, Singh AK. Effect of IBA and planting containers on shoot and root characters and survival of litchi airlayers. Indian Journal of Horticulture. 2006; 63(2):155-158.

25. Singh PC, Shukla HS, Katiyar PN. Effect of indole butyric acid and p-hydroxybenzoic acid on regeneration of litchi cultivars through air layering. Annals of Horticulture. 2009; 2(2):194-196.

26. Tyagi SK, Patel RM. Effect of growth regulators on rooting of air layering of guava (Psidium guajava L.) cv. Sardar Guava. The Orissa Journal of Horticulture. 2004; 32(1):58-62.

27. Das AK, Prasad B. Effect of plant growth regulators on rooting survival of air layering in litchi. Advance Research Journal of Crop Improvement. 2014; 5(2):126-130.

28. Brahamchari VS, Singh MP, Yadav GS. Effect of etiolation and growth substance on success of marcottage in litchi. The Orissa Journal of Horticulture. 1997; 25(2):87-89.

29. Lal H, Singh VP, Rao VK. Vegetative propagation of kiwi fruit. Progressive Horticulture. 2001; 33(1):99-100.

30. Chatterjee BK. Effect of different concentration of growth regulators on rooting and survival percentage of mango air-layers. Punjab Horticultural Journal. 1982; 22(34):128-130.

31. Pathak RK, Pandey D, Pandey US. Effect of IBA concentrations and bottom heat on rooting of plum cuttings. Progressive Horticulture. 1975; 7(1):17-21.

32. Tomar KS. Studies on rooting and growth of karonda (Carissa carandas L.) air layers with \& without growth regulators. Thesis submitted to Jawaharlal Nehru Krishi Vishwavidyalaya, Jabalpur. 1979.

33. Wada S, Tanimoto E, Masuda Y. Cell elongation and metabolic turnover of cell wall as affected by auxin and cell wall degrading enzymes. Plant and Cell Physiology. 1968; 9(2):369-376.

34. Singh PC, Shukla HS, Katiyar PN. Effect of indole butyric acid and p-hydroxybenzoic acid on regeneration of litchi cultivars through air layering. Annals of Horticulture. 2009; 2(2):194-196.

35. Rahman MA, Amin MN, Islam MS, Begum MM, Uddin MA. Rooting and survival of air layers in litchi as influenced by layering time and plant growth regulator. Pakistan Journal of Biological Science. 2002; 5 (11):12591260.

36. Singh P, Chandrakar J, Singh AK, Jain V, Agrawal S. Effect on rooting in guava cv. Lucknow-49 through PGR 
and organic media under Chhattisgarh condition. Acta Horticulturae. 2007; 735:197-199.

37. Bhosale VP, Jadav RG, Masu MM. Response of different Medias and PGR's on rooting and survival of air layers in pomegranate [Punica granatum (L.)] cv. Sindhuri. The Asian Journal of Horticulture. 2010; 4(2):194-197.

38. Chawla W, Mehta K, Chauhan N. Influence of plant growth regulators on rooting of litchi (Litchi chinensis Sonn.) air layers. The Asian Journal of Horticulture, 2012; 7(1):160-164.

39. Patel DM, Nehete DS, Jadav RG, Satodiya BN. Effect of PGRs and rooting media on air layering of different pomegranate (Punica granatum L.) cultivars. The Asian Journal of Horticulture. 2012; 7(1):89-93.

40. Sen PK, Bose TK, Sasibhusahan T. Propagation of mango (Mangifera indica L.) by air layering with 1 growth substances. Indian Agriculturist. 1961; 5(2):167-72.

41. Kumar P. Influence of plant growth regulators and various hardening treatments on rooting and survival of air layers in litchi (Litchi chinensis Sonn.). Thesis submitted to G.B. Pant University of Agriculture and Technology, Pantnagar, U.S. Nagar, Uttarakhand (India), 2009.

42. Sinha R, Ray SKD. Effect of different growth regulators in air layering of litchi cv. Bombai. Horticulture Journal, 2002; 15(1):63-67.

43. Hatibarua P, Gogoi S, Mazumder A. Adventitious rooting in jackfruit (Artocarpus heterophyllus Lam.) air layers induced with etiolation and rooting hormones. Annals of biology Ludhiana. 1997; 13(1):155-159.

44. Singh S, Jawandha JS. Propagation studies in litchi. Punjab Horticultural Journal. 1981; 21(3-4):184-187.

45. Rymbai H, Reddy GS. Effect of IBA, time of layering and rooting media on air-layers and plantlets survival under different growing nursery condition in guava. Indian Journal of Horticulture. 2010; 67:99-104.

46. Kumar M, Lal S, Kumar R, Kamal S. Response of indole butyric acid on air layering in jackfruit cv. Pant Garima. Environment \& Ecology. 2007; 25(4):1167-169.

47. Shukla GS, Bist LD. Studies on the efficacy of IBA and NAA on clonal propagation by cutting in low chilling pear rootstocks. Indian Journal of Horticulture. 1994; 51(4):351-357. 